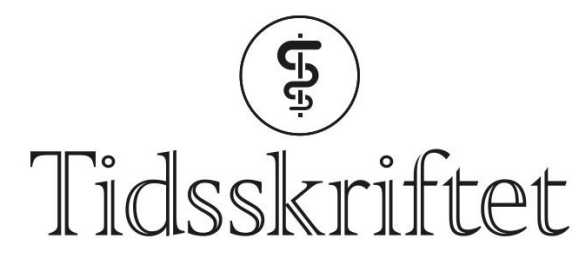

DEN NORSKE LEGEFORENING

\title{
Om å bli rammet av kreft
}

ANMELDELSER

JAKOB LUNDEBY KIRKEBAK

Lege i spesialisering, Sykehuset Østfold

Moss DPS

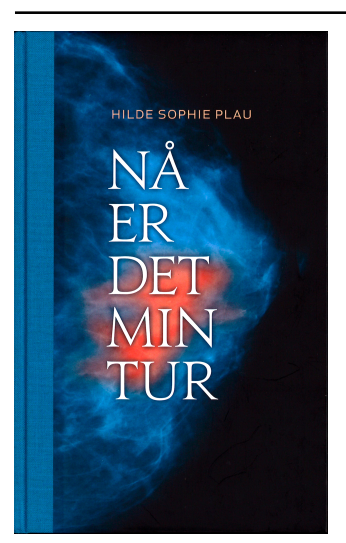

Hilde Sophie Plau

Nå er det min tur

219 s. Oslo: Humanist forlag, 2017. Pris NOK 369

ISBN 978-82-8282-155-1

Brystkreft er den hyppigste kreftformen for kvinner. De fleste leger og legfolk kjenner noen som er blitt rammet. Jeg-fortelleren i Nå er det min tur er blitt en av kreftfolket, et nummer i rekken. Hun er blant disse hordene av kvinner som hvert år gjennomgår diagnostisering, behandling og alle dens bivirkninger. Kanskje er boken skrevet for dem - eller for alle de som «kjenner en», eller for helsepersonell og alle de mange hjelperne som svinger seg $\mathrm{i}$ dansen rundt brystkreftpasienter i det norske helsevesenet.

Boken gir et usminket bildet av hvordan kreftbehandling faktisk foregår. Her er innkallinger som blir borte i posten, FEC, VAP og mikrokalk - og bryst som fjernes med «øsehugg».

Samtidig er tonen i boken mer forsonende enn amper, mer engasjert enn resignert. Man får inntrykk av at denne personlige beretningen utgjør en form for egenterapeutisk arbeid. Slik kan den forstås som et forsø $\mathrm{k}$ på å samle trådene, få oversikt og eierskap til en helhetlig fortelling, og på den måten la sykdommen bli et substrat mer enn et resultat.

Nå er det min tur gir en kronologisk fremstilling av et pasientforløp. Som tekst er den lettlest og luftig, inndelt i mange korte avsnitt og kapitler. Dens form og karakter endres gjennom boken som om den reflekterer sykdommens faser. Den blir mer stakkato og stikkordspreget 
når den beskriver perioder der sykdommen tar det meste av kreftene, og den vider seg ut og flyter bedre når den tar opp i seg lysglimt i form av barndomsminner eller hverdagslige møter med barnebarn.

Første side tar oss med ned i kroppens indre, til celler der mutasjonene stables i høyden og der det bygges funksjonelle veinett i det tilsynelatende kaoset.

«Å få kreft er som å bli avbrutt midt i en setning. Hva var jeg? Hvordan var jeg, og hvordan levde jeg før kroppen ble rammet, mens jeg var hel og intakt? Som et barn, tenker jeg nesten. Skånet.»

Nå er det min tur gir en stemme til kreftfolket. Den er spekket med skarpe observasjoner, og er rett som det er fornøyelig skrevet. Boken må sies å kunne være av allmennmenneskelig interesse. God lesing.

Publisert: 19. februar 2018. Tidsskr Nor Legeforen. DOI: 10.4045/tidsskr.17.10oo

(C) Tidsskrift for Den norske legeforening 2020. Lastet ned fra tidsskriftet.no 